University for Business and Technology in Kosovo

UBT Knowledge Center

Oct 28th, 9:00 AM - Oct 30th, 5:00 PM

\title{
Assessment of Reinforced Concrete Half Joint According to EN $-1992-1-1$
}

Xhemshir Mulliqi

University of Zagreb, xhemshir_mulliqi@yahoo.com

Follow this and additional works at: https://knowledgecenter.ubt-uni.net/conference

Part of the Engineering Commons

\section{Recommended Citation}

Mulliqi, Xhemshir, "Assessment of Reinforced Concrete Half Joint According to EN -1992-1-1" (2016). UBT International Conference. 13.

https://knowledgecenter.ubt-uni.net/conference/2016/all-events/13

This Event is brought to you for free and open access by the Publication and Journals at UBT Knowledge Center. It has been accepted for inclusion in UBT International Conference by an authorized administrator of UBT Knowledge Center. For more information, please contact knowledge.center@ubt-uni.net. 
Book of Proceedings

International Conference on Civil Engineering, Infrastructure and Environment

\title{
Assessment of Reinforced Concrete Half Joint According to EN -1992-1-1
}

\author{
Xhemshir Mulliqi \\ University of Zagreb, Faculty of Civil Engineering \\ xhemshir_mulliqi@yahoo.com
}

\begin{abstract}
A half-joint is a particular type of RC structure .When using precast beams in reinforced concrete frame structures, dapped beams ends are often required in the bearing area to keep the floor structure as thin as possible. The arrangement and detailing of the reinforcement is an important factor in the performance of a half-joint. For pre-tensioned members, the prestressing force and tendons should be ignored, but for post-tensioned members the prestressing force should be considered as an external force acting on the half-joint. This paper aims to calculate dapped beam ends according to the EN 1992-1-1.
\end{abstract}

Keywords: Half-joint, Reinforcement, Strut-and-tie model, Tensile force

\section{Introduction}

When using precast beams in reinforced concrete frame structures, dapped beams ends are often required in the bearing area to keep the floor structure as thin as possible. Because anchorage of the diagonal tie Zs is difficult due to the geometrical conditions in strut-and-tie models with an inclined reinforcement portion of $100 \%$, a combined strut-and-tie model comprising perpendicular and inclined suspension reinforcement is selected under normal conditions.

This paper aims to calculate dapped beam ends or a half-joint according to the EN 1992-1-1.[1]

\section{Half-joint calculation in accordance with EN 1992-1-1}

The calculation is based on a strut-and-tie model combined of perpendicular and inclined suspension reinforcement in accordance with DAfStb ${ }^{1}$ Booklet 399.[2]

The equilibrium in the strut and-tie model is determined by iterative addition of the required stirrups and the recalculation of the centres of gravity of the reinforcement.

Strut-and-tie model consisting of inclined suspension reinforcement.

The inclined model is always used in combination with the model of perpendicular suspension reinforcement to prevent shearing of the half joint along the inclined bars. This model is more suitable for mapping the actual load-bearing behaviour of higher beam corbels.

\footnotetext{
${ }^{1}$ German Committee for Reinforced Concrete
} 


\subsection{Tensile force in the inclined reinforcement:}

$\mathrm{F}_{\mathrm{ZV}}=\left(\mathrm{F}_{\mathrm{ed}}-\mathrm{F} 1_{\mathrm{ed}}\right) \cdot$ inclined reinforcement portion

\subsection{Strut-and-tie model consisting of perpendicular suspension reinforcement}

While the model of inclined suspension reinforcement results directly from the support geometry, the geometry of the model of perpendicular reinforcement is determined through the dimensioning of the nodes 1 and 2 of the inclined strut (D1), see Figure 2.
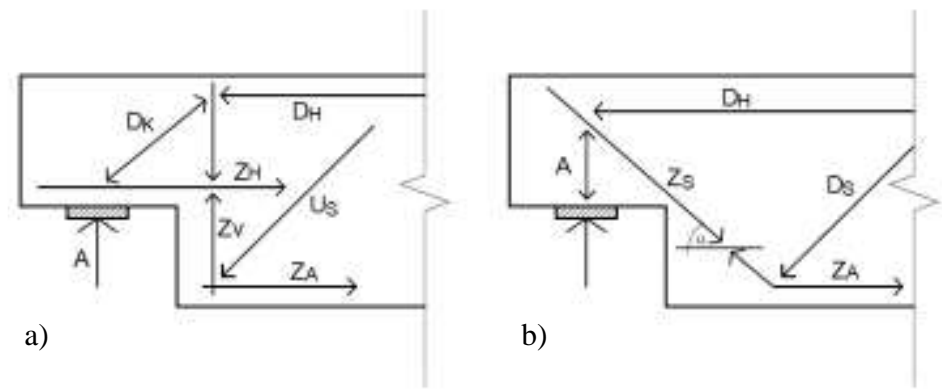

Fig. 1. Strut-and-tie model a) and an alternative Strut-and-tie model b)

It is assumed that the stress limit in node 2 (stress $\sigma \mathrm{cd} 2$ depends on a4 ) is complied

$$
\sigma \mathrm{Rdmax}=\mathrm{k} 2 \cdot v^{\prime} \cdot \mathrm{fcd}
$$

with; $\mathrm{k} 2$ and $\mathrm{v}^{\prime}$ are assumed in accordance with the selected National Annex (NA).

$$
\begin{aligned}
& \text { - for Germany: } \mathrm{k} 2=0.75, v^{\prime}=1.1-\mathrm{fck} / 500<=1.0 \\
& \text { - for Austria: } \quad \mathrm{k} 2=0.9, v^{\prime}=1.0 \text { - fck } / 250<=1.0
\end{aligned}
$$

The exact compression strut position with the dimensions of the nodes 1 and 2 is determined in the above expressions and the given border conditions such as the concrete cover and the centre of gravity of the suspension reinforcement and the horizontal reinforcement.By defining unfavourable half joint dimensions and/or if a high number of reinforcement layers is required, an inclination of the compression strut below $30^{\circ}$ can result. 
Book of Proceedings

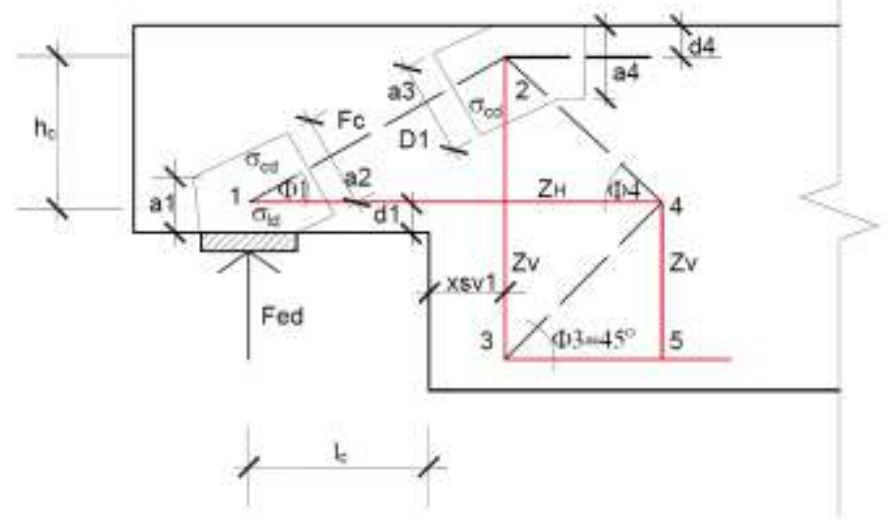

Fig. 2. The geometry of the strut-and-tie model

\subsection{Tensile force in the vertical suspension reinforcement:}

Compression strut inclination:

$$
\mathrm{F}_{\mathrm{ZV}}=\left(\mathrm{F}_{\mathrm{ed}}-\mathrm{F} 1_{\mathrm{ed}}\right) \cdot(1-\text { inclined reinforcement portion })
$$

$$
\begin{gathered}
\Phi_{1}=\operatorname{atan}\left(\frac{\mathrm{h}_{\mathrm{c}}}{\mathrm{l}_{\mathrm{C}}}\right) \\
\sigma_{\mathrm{cd} 2}=\frac{\mathrm{F}_{\mathrm{ZH}}}{\left(\mathrm{b}_{\mathrm{k}} \cdot \mathrm{a} 4\right)} \\
\mathrm{b}_{\mathrm{k}}=\text { half-joint width; } \mathrm{F}_{\mathrm{ZH}}=\mathrm{F}_{\mathrm{ZV}} \cdot \frac{\mathrm{l}_{\mathrm{C}}}{\mathrm{h}_{\mathrm{C}}} \\
\text { Compressive strut force: } \mathrm{F}_{\mathrm{C}}=\mathrm{F}_{\mathrm{ZV}} / \sin \left(\Phi_{1}\right)
\end{gathered}
$$

\subsection{Horizontal forces due to the compressive strut geometry that are to be} anchored:

$$
\mathrm{F}_{\mathrm{ZH}}=\left(\mathrm{F}_{\mathrm{ZV}}+\mathrm{F} 1_{\mathrm{ed}}\right) \cdot\left(\frac{\mathrm{l}_{\mathrm{C}}}{\mathrm{h}_{\mathrm{C}}}\right)+\mathrm{H}_{\mathrm{ed}}
$$

\subsection{Verification of the load-bearing capacity of the compressive concrete strut:}

Compliance with the following condition must be verified

$$
\begin{gathered}
\mathrm{F}_{\mathrm{ed}} \leq \mathrm{V}_{\mathrm{rd}, \text { max }} \\
\mathrm{V}_{\mathrm{rd}, \text { max }}=\alpha_{\mathrm{cv}} \cdot \mathrm{b}_{\mathrm{v}} \cdot z \cdot v_{1} \cdot \mathrm{f}_{\mathrm{cd}} /(\cot \theta+\tan \theta)
\end{gathered}
$$

Where:

$\alpha_{c v}$ is a coefficient taking account of the state of the stress in the compression chord $\mathrm{b}_{\mathrm{v}}$ is the minimum width between tension and compression chords

$z$ is the inner lever arm, for a member with constant depth, corresponding to the 
bending moment in the element under consideration, the approximate value $z=0.9 \cdot d$ may normally be used.

$v_{1}$ is a strength reduction factor for concrete cracked in shear

$\mathrm{f}_{\mathrm{cd}}$ is design value of concrete compressive strength

$\theta$ is the angle between the concrete compression strut and the beam axis perpendicular to the shear force, The angle $\theta$ should be limited

$$
1 \leq \cot \theta \leq 2.5
$$

\subsection{Verification of node 1 (bearing stress):}

The verification of the compressive stress underneath the load plate is based on EN 1992-1-1: With the following conditions underneath the load plate:

$$
\sigma_{\mathrm{ld}}=\frac{\mathrm{F}_{\mathrm{ed}}}{\left(\mathrm{l}_{\mathrm{p}} \cdot \mathrm{b}_{\mathrm{p}}\right)} \leq \sigma_{\mathrm{rd}}=\mathrm{k}_{2} \cdot v^{\prime} \cdot \mathrm{f}_{\mathrm{cd}}
$$

$\mathrm{k}_{2}$ and $v^{\prime}$ in accordance with the applicable National Annex (NA)

- for Germany: $\mathrm{k}_{2}=0.75, v^{\prime}=1.1-\mathrm{f}_{\mathrm{ck}} / 500 \leq 1.0$

- for Austria: $\mathrm{k}_{2}=0.9, v^{\prime}=1.0-\mathrm{f}_{\mathrm{ck}} / 250$

$$
\text { and in node 1: }
$$$$
\mathrm{a} 1(1)=2 \cdot \mathrm{d}_{1}
$$

$$
\mathrm{a} 2(1)=\left(\mathrm{a} 1(1) \cdot\left(\frac{\mathrm{l}_{\mathrm{C}}}{\mathrm{h}_{\mathrm{C}}}\right)+\mathrm{l}_{\mathrm{p}}\right) \cdot \sin \left(\Phi_{1}\right)
$$

$$
\sigma_{\mathrm{cd}}=\frac{\mathrm{F}_{\mathrm{c}}}{\mathrm{a} 2(1) \cdot \mathrm{b}_{\mathrm{p}}} \leq \sigma_{\mathrm{rd}}=\mathrm{k}_{2} \cdot v^{\prime} \cdot \mathrm{f}_{\mathrm{cd}}
$$

$\mathrm{k}_{2}$ and $v^{\prime}$ as with node 1 for bearing stress, $\sigma \mathrm{ld}$ and $\sigma \mathrm{cd}$ can be limited to $0.85 \cdot \mathrm{f}_{\mathrm{cd} 1}$ in accordance with Schlaich/Schäfer.

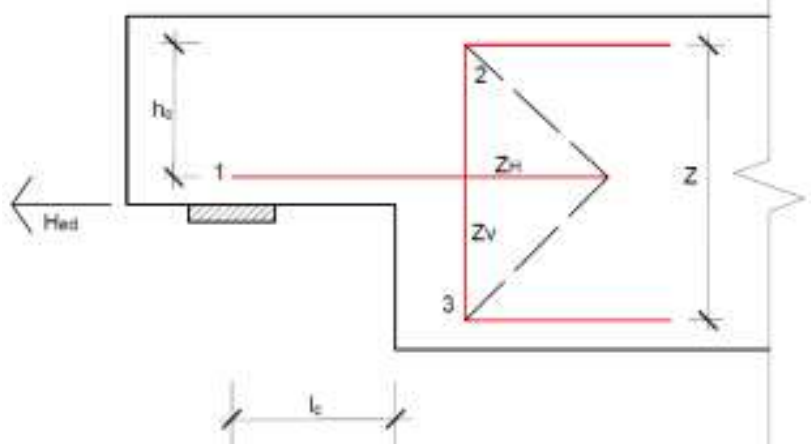

Fig. 3. Model for the back anchorage of the horizontal force

The tensile force of the vertical suspension reinforcement:

$\mathrm{F}_{\mathrm{ZV}}=\left(\mathrm{F}_{\mathrm{ed}}-\mathrm{F} 1_{\mathrm{ed}}\right) \cdot(1-$ inclined reinforcement portion $)+\mathrm{H}_{\mathrm{ed}} \cdot \frac{\mathrm{h}_{\mathrm{c}}}{\mathrm{z}}$ 
Book of Proceedings

International Conference on Civil Engineering, Infrastructure and Environment

\section{Worked example Design of Half Joint Using Strut-Tie Model}

The beam in fig. 4 . is $7.0 \mathrm{~m}$ simply suported.The beam is $140 \mathrm{~cm} \times 75 \mathrm{~cm}$ broad.The height of the half joint hk is $65 \mathrm{~cm}$ while the length of the half joint $\mathrm{lk}$ is $50 \mathrm{~cm}$ at each end.The beam supports a uniformly distributed load of $200 \mathrm{Kn} / \mathrm{m}$.Assume C30/37 Mpa and B500B Mpa.[3]

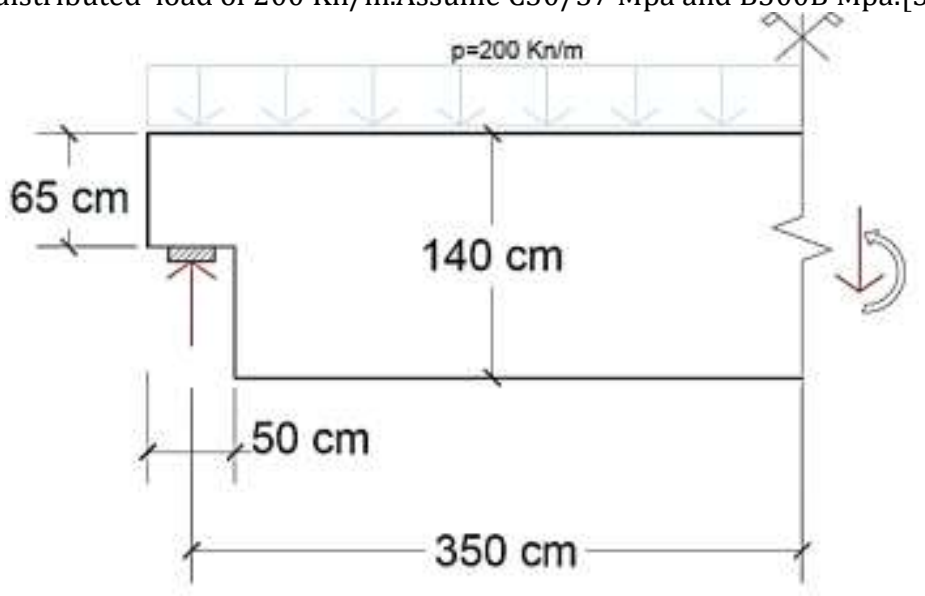

Fig. 4. A reinforced concrete "Half Joint" beam

Analysis:

CROSS SECTION

$$
\mathrm{A}=\mathrm{p} \times(\mathrm{L} / 2+0.5 / 2)=200 \times 3.75=750 \mathrm{Kn}
$$

Bending moment at mid-span $=750 \times 3.50-200 \times 3.75^{2} / 2=1218.75 \mathrm{Knm}(20)$

$$
\begin{gathered}
\mathrm{d} 1=\mathrm{c}+\phi / 2=4.0+2.0 / 2=5.00 \mathrm{~cm} \\
\mathrm{~d}=\mathrm{h}-\mathrm{d} 1=140-5.25=135 \mathrm{~cm}
\end{gathered}
$$

cross section values $\mathrm{zu}=70 \mathrm{~cm} \quad \mathrm{Ac}=1.0500 \mathrm{~m} 2 \quad \mathrm{Ic}=0.17150000 \mathrm{~m} 4$

BENDING DESIGN kd- method (x/d < 0.448), Myd = $1218.80 \mathrm{kNm}(24)$

$\varepsilon 1=-2.85 \mathrm{o} / \mathrm{oo} \quad \varepsilon 2 \mathrm{~s}=45.00 \mathrm{o} / \mathrm{oo} \quad \mathrm{x} / \mathrm{d}=0.07 \quad \mathrm{z} / \mathrm{d}=0.97 \mathrm{kd}=3.35$

required Bottom longitudinal reinforcement $(\mathrm{Asb})=19.85 \mathrm{~cm}^{2} \quad \mu=0.19 \%$ Provide:7R $\phi 20=21.98 \mathrm{~cm}^{2}$

Top longitudinal reinforcement (As'): 4 \$ $20=12.57 \mathrm{~cm} 2$

Table 1. Pulled up bearing by EN 1992-1-1:2004 C 30/37 B500B

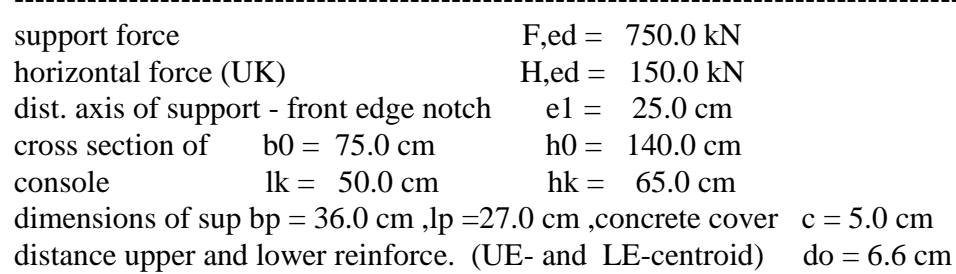


Assessment of Reinforced Concrete Half Joint According to EN -1992-1-1

\section{MODEL OF FRAMEWORK - GEOMETRY}

pressure strut D1 (in console ) :dimensions l(hor) $=56.0 \mathrm{~cm} \mathrm{~h}$ (vert) $=43.2 \mathrm{~cm}$ inclination $\phi 1=37.63 \mathrm{degr}$.

node 1 (below) a1=18.0 $\mathrm{cma} 2=32.9 \mathrm{~cm}$

node 2 (above) $44=13.2 \mathrm{cmd} 4=6.6 \mathrm{~cm}$

tied arch $\mathrm{Zh}$ ( horizontal reinforcement ) :

distance to upper edge beam $\quad \mathrm{h} 1=49.8 \mathrm{~cm}$

tied $\operatorname{arch~} \mathrm{Zv}$ ( suspension reinforcement) :distance to front edge notch $\mathrm{d} 1=28.0 \mathrm{~cm}$

distance from axis of support $\mathrm{da}=53.0 \mathrm{~cm}$

Tie ZV2 (suspension reinforcement 2):distance to front edge notch $\mathrm{d} 2=111.6 \mathrm{~cm}$

\section{Internal forces}

for vert. stirrups ZV1 (with contribution for vert. stirrups ZV2

horizontal tensile force

$\mathrm{Zv}=819.1 \mathrm{kN}$

$\mathrm{Zv}=972.9 \mathrm{kN}$

Design

$\mathrm{Zh}=1175.7 \mathrm{kN}$

carrying capacity $\mathrm{Fv}=750.00 \mathrm{kN}<\mathrm{V}, \mathrm{rdmax}=1406.23 \mathrm{kN}$

trans. tens.force $\mathrm{Ftd}=86.25 \mathrm{kN}$

pressure at supp. $\sigma, 1 \mathrm{~d}=7.72 \mathrm{~N} / \mathrm{mm} 2<\sigma, \operatorname{rdmax}=12.72 \mathrm{~N} / \mathrm{mm} 2$

inpressure strut $\sigma, \mathrm{cd}=10.36 \mathrm{~N} / \mathrm{mm} 2<\sigma, \mathrm{rdmax}=12.72 \mathrm{~N} / \mathrm{mm} 2$

suspens.stirr ZV1 Ac,req=18.84 cm2< Ac,exis $=20.34 \mathrm{~cm} 2$

suspens.stirr.ZV2 Ac,req $=22.38 \mathrm{~cm} 2<$ Ac, exis $=22.60 \mathrm{~cm} 2$

horizont.stirrups Ac,req=27.04 cm2<Ac,exis $=31.40 \mathrm{~cm} 2$

reinforcement

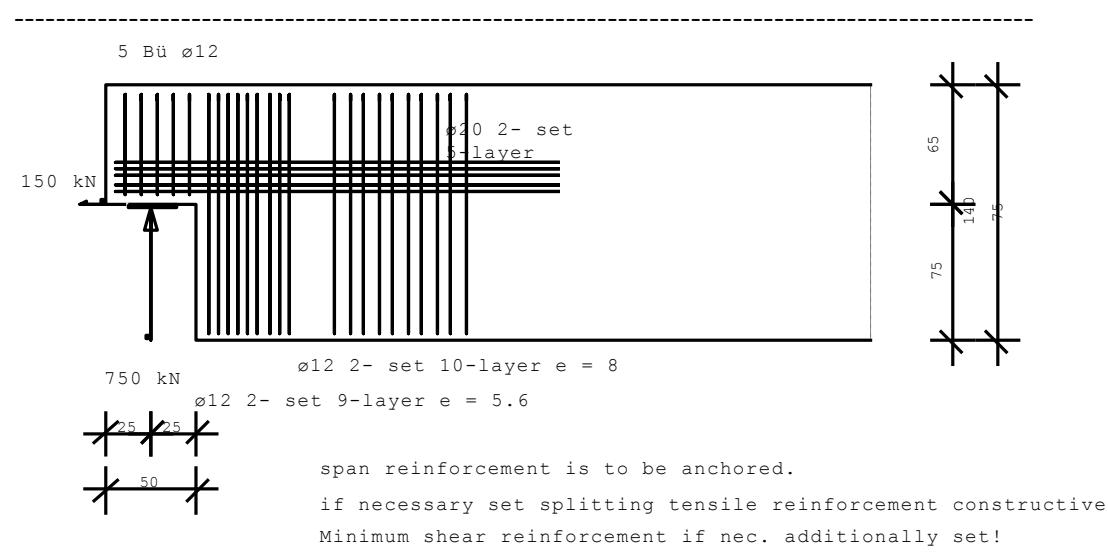

Fig. 5. A reinforcement of concrete "Half Joint" beam[4] 
Book of Proceedings

International Conference on Civil Engineering, Infrastructure and Environment

\section{Conclusions}

The EC2 model avoid any unsafe predictions in the shear strength. Adequate anchorage should also be provided for the tensile steel reinforcement at the supports to prevent premature reinforcement slip failure.As shown in fig.5. the following stirrups are provided: ZV1 $\varnothing 122$ - set in 9 layers with 20.34 $\mathrm{cm} 2$, for ZV2 $\varnothing 122$ - set in 10 layers with $22.60 \mathrm{~cm} 2$ and for horizontal stirrups $\varnothing 202$ - set in 5 layers with $31.40 \mathrm{~cm} 2$. The Eurocode 2 strut-and-tie model can be unsafe when av/d ratio is in between 1 and 2.

\section{References}

1. EN 1992-1-1 (2004) (English): Eurocode 2: Design of concrete structures - Part 1-1: General rules and rules for buildings [Authority: The European Union Per Regulation 305/2011,

2. Directive 98/34/EC, Directive 2004/18/EC]

3. Booklet 399 of the German Committee for Reinforced Concrete DAfStb)

4. Bhatt, P.,.Mac Ginlay, Th., Cho., B. S.: Reinforced Concrete Design to Eurocodes,(2014) Frilo Statik, Software for structural calculation and design 